\title{
ANALIZA VANJSKE POLITIKE SOCIJALISTIČKE JUGOSLAVIJE: AKTERI I STRUKTURE
}

\author{
Dejan Jović \\ Fakultet političkih znanosti \\ Sveučilišta u Zagrebu \\ E-mail: dejan.jovic@fpzg.hr
}

\author{
DOI: $10.20901 / a n .14 .07$ \\ Izvorni znanstveni rad \\ Prihvaćeno: ožujak 2018.
}

\begin{abstract}
Sažetak Ova analiza vanjske politike socijalističke Jugoslavije, a posebno razdoblja vladavine Josipa Broza Tita, prvo je politološko razmatranje te teme nasuprot većini studija koja se njome bave iz historiografske perspektive. U prvom dijelu članka prikazani su glavni elementi analize vanjske politike, pri čemu se autor usredotočuje na odnos aktera i struktura kao jedan njezin element. $U$ drugom dijelu prikazane su teorijske i metodološke postavke na kojima se zasniva analiza vanjske politike socijalističke Jugoslavije. Autor zaključuje da je proces odlučivanja o vanjskoj politici Jugoslavije evoluirao od 1945. do 1980. tako što je Tito, kao glavni donositelj odluka, sve više morao voditi računa o strukturi i raznim akterima unutar nje. Očita je bila sve veća pluralizacija procesa odlučivanja, kako na horizontalnoj razini, u interakciji Saveznog sekretarijata za inozemne poslove, partijskog vrha i Titova kabineta, tako i na vertikalnoj osi, kroz utjecaj republika i pokrajina na odlučivanje na saveznoj razini. lako je ostao glavni donositelj odluka, Titovu su moć s vremenom znatno ograničili utjecaji drugih aktera, osobito otkako je sedamdesetih godina Predsjedništvo SFRJ dobilo mnoge ovlasti.
\end{abstract}

Ključne riječi analiza vanjske politike, akteri i strukture, jugoslavenska vanjska politika, Josip Broz Tito, hrvatska vanjska politika

\section{Uvod}

Vanjska politika socijalističke Jugoslavije $\mathrm{e}^{1}$ ponekad se ističe kao velik, čak spektakularan, uspjeh države koja je s prvim međunarodnim priznanjima svojih država-sljednica 15. siječnja 1992. prestala postojati. Bio je to primjer države koja je formirala vlastiti identitet $\mathrm{u}$ međunarodnoj politici i imala nadprosječan utjecaj na nju, pogotovo ima li se na umu da je Jugoslavija bila zemlja srednje veličine: prema broju stanovnika 1989, bila je osma država u Europi i ubrajala se u srednje razvijene europske zemlje. Vanjska politika uzdignula je
Jugoslaviju na međunarodnoj političkoj pozornici, kako zbog proaktivnog načela koje je promovirala naročito kroz pokret nesvrstanih (Jakovina 2011) i politiku miroljubive aktivne koegzistencije (Mates 1974) tako i zbog međunarodnih okolnosti na koje je samo djelomično utjecala, ali ih je znala iskoristiti.

Jugoslavija nije bila jednoznačno klasificirana kao mala zemlja ili zemlja srednje veličine. Vukadinović (1970) je tretira i kao malu zemlju i kao zemlju srednje veličine, naglašavajući da su suprotnosti između tih zemalja i velikih sila bile jedno od glavnih obilježja hladnoratovskoga, odnosno postimperijalnog svijeta. Ideju 
Jugoslavija je iskoristila i to što je bila saveznica pobjedničkih sila u Drugome svjetskom ratu i jedna od osnivačica UN-a. Svoj je međunarodni politički položaj učvršćivala i inicijativama na području međunarodnih ekonomskih odnosa, primjerice kroz Konferenciju za trgovinu i razvoj UN-a (UNCTAD) i Grupu 77. koja je okupljala manje razvijene i nerazvijene zemlje. Česti i brojni posjeti jugoslavenskih političara, naročito Josipa Broza Tita, drugim zemljama, kao i posjeti stranih državnika Jugoslaviji povećali su ugled i važnost zemlje u globalnoj politici. No najvažniji razlog uspješne vanjske politike bilo je njezino ozbiljno koncipiranje koje je, posebno od sredine pedesetih godina, učinilo prepoznatljivom vanjskopolitičku doktrinu čiji je glavni element bila politika miroljubive aktivne koegzistencije (Mates 1974).

$S$ obzirom na ocjene o relativnoj uspješnosti jugoslavenske vanjske politike, neobično je što o njoj postoje samo historiografske, a ne i politološke

nesvrstavanja povezuje s pokušajem zemalja male i srednje veličine, naročito onih koje su se u hladnoratovskom razdoblju oslobodile kolonijalizma, da utječu na međunarodnu politiku. Da bi se to dogodilo, bilo je potrebno demokratizirati međunarodne odnose. U članku o malim državama i politici nesvrstavanja Vukadinović (1970: 421) naglašava da je neravnopravnost velikih i malih država jedan od izvora nestabilnosti u svijetu. "Za Jugoslaviju kao malu evropsku zemlju politika nesvrstavanja postala je odavno sastavni dio općeg društveno-političkog razvoja i bilo bi nemoguće zamisliti odstupanje od tog kursa koji daje maksimalne mogućnosti za slobodni pristup međunarodnim odnosima". U drugom članku Vukadinović (1988: 4) Jugoslaviju tretira i kao malu i kao "srednju državu". "Srednjom" su je činili "snažno univerzalno djelovanje i velik interes za svjetska kretanja i procese". U svojim govorima Tito je također koristio pojmove "mala" i "srednja" zemlja. O klasifikaciji zemalja prema veličini i snazi v. Jović 2011; Luša i Mijić 2012; Katzimeris 2009; Maass 2009. studije. To je još nerazumljivije ima li se na umu da je analiza vanjskih politika (foreign policy analysis) kao posebna poddiscipina, koja je nastala na granici između studija međunarodnih odnosa, javnih politika, komparativne politike i studija političke psihologije, osmišljena još pedesetih, a intenzivno se razvijala šezdesetih i sedamdesetih godina 20 . stoljeća, dakle upravo u doba uspona i vrhunca jugoslavenske vanjske politike. Osamdesete godine, kojima je nakratko dominirala komparativna vanjska politika, bile su doba krize jugoslavenske vanjske politike.

Jugoslavensku vanjsku politiku analizirali su i neki autori koji su utjecali na razvoj poddiscipline. Hans J. Morgenthau u članku u New York Times Magazine 18. travnja 1965. piše da se SAD ne suočava više samo $s$ jednom nego $s$ više vrsta komunizma, pa na komunistički blok ne treba gledati kao na čvrstu i jedinstvenu cjelinu. "Ustvari, Tito, koji je komunist, danas pokazuje manje neprijateljski stav prema SAD-u od De Gaullea, koji to nije" (nav. u: Smith i dr. 2012: 46). Morgenthau naziva jugoslavenski komunizam neovisnim, stvorivši kategoriju neovisni komunizam, koja je uglavnom ostala nepoznatom i nije korištena ni u jugoslavenskoj politici ni u politologiji. To ne čudi ako se zna da nijedno Morgenthauovo djelo, uključujući klasičnu knjigu Politics among Nations, nije prevedeno ni u Jugoslaviji ni u državama-sljednicama, osim Slovenije.

U ovome članku analiziram vanjsku politiku socijalističke Jugoslavije iz politološke perspektive. Zbog ograničena prostora moram se fokusirati samo na neke aspekte vanjske politike: na odnose aktera i struktura u formiranju jugoslavenske vanjske politike. Izvan fokusa morao sam ostaviti brojne teme, kao što su periodizacija jugoslavenske vanjske politike, ideje i diskursi koji su se razvili u okviru nje, te percepcije i identitete. 


\section{Što je analiza vanjske politike?}

Iako se vanjska politika akademski proučavala u sklopu studija međunarodnih odnosa, prve sustavnije analize kojima se nastoji konstituirati kao posebna poddisciplina pojavljuju se pedesetih godina u zapadnoj, poglavito američkoj, politologiji. U knjizi Foreign Policy Analysis Valerie Hudson navodi da je ta poddisciplina rođena 1954. kada je objavljena kratka studija, gotovo pamflet na 130 stranica, Decision-Making as an Approach to the Study of International Politics Snydera, Brucka i Sapina. Izvorni autor bio je, kako kasnije navodi Sapin, Richard C. Snyder, koji se smatra i najzaslužnijim za konstituiranje nove poddiscipline. Riječ je o pokušaju da se analiza vanjske politike ustanovi kao posebno polje studija međunarodnih odnosa, neovisno o tome tretira li se kao podskup studija međunarodnih odnosa ili kao posebna grana koja djelomice pripada međunarodnim odnosima, a djelomice je otvorena prema političkoj psihologiji, sigurnosnim studijama, međunarodnom pravu, međunarodnoj političkoj ekonomiji, kulturološkim studijama, povijesti, sociologiji i drugim disciplinama. Jedan od motiva razvoja bio je da se analiza vanjske politike približi praktičnoj, analitičarskoj svrsi.

"Autori žele izraziti svoje duboko uvjerenje da polje, kao što je međunarodna politika, nije samo zbrkana mješavina ideja koje su u prošlosti - zbog jednoga ili drugog razloga - smještene u isti lonac. Ono se ponajprije sastoji od niza empirijskih problema koji su povezani nekom logikom i koji imaju vrlo specifične indikatore koji se mogu istraživati. Ti problemi, neovisno o tome kako su nastali, moraju se analizirati onako kako to odgovara karakteru ovog zadatka. Stoga smo smatrali nužnim da stvorimo vlastitu istraživačku matricu, oslanjajući se na radove i metode onih autora koje politolozi najčešće ne koriste" (Snyder, Bruck i Sapin 2002: 22).

Izdvajanje studija vanjskih politika iz cjeline međunarodnih odnosa imalo je djelomice strukovnu svrhu: pripremiti buduće diplomate, tvorce političkih odluka, analitičare i stručnjake da što bolje razumiju prirodu procesa odlučivanja u toj posebnoj kategoriji javnih politika (Petek 2012) na koju bi se mogli, kako tvrdi Rosenau (1966), primijeniti i modeli razvijeni za analizu domaćih javnih politika, ali i međunarodnih odnosa. Istodobno, analiza vanjske politike fokusira se na proces donošenja odluka, oslanjajući se na psihologiju, nauku o organizacijama, kulturologiju i povijesnu znanost. Kompleksan pristup koji je u međuvremenu razvijen u okviru te poddiscipline u dvjema fazama, od 1954. do 1973. i od 1973. do danas, vidljiv je iz knjige Foreign Policy Analysis (2014) Valerie Hudson u kojoj autorica identificira devet razina o kojima analiza vanjske politike mora voditi računa: (1) kognitivni procesi u donošenju odluka, (2) osobnost i karakter političkih vođa koji donose odluke, (3) dinamika odlučivanja u malim skupinama koje donose odluke ili sudjeluju u njihovu donošenju, (4) organizacijski procesi, (5) birokratske politike, (6) pitanja kulture i identiteta, (7) unutarnja politička dinamika, uključujući dinamiku odnosa vlasti i opozicije, 8) svojstva države (geografska, ekonomska, resursi i dr.) i (9) karakter regionalnih sustava i međunarodnog sustava u trenutku donošenja odluka. S tako širokom lepezom tema, analiza vanjske politike izlazi iz okvira koje je postavila teorija međunarodnih odnosa. Ona je, naročito u sklopu neorealizma, razvila model utemeljen na dinamici odnosa država i međunarodnog sustava (Waltz 1979), smatrajući da su države akteri po sebi. Teorije međunarodnih odnosa tretiraju države 
kao aktere, iako to ne čine sve na jednak način. Analiza vanjske politike polazi od suprotne postavke: ona desubjektivira države tretirajući ih primarno kao rezultat interakcije pojedinaca, naročito onih koji imaju političku moć da utječu na karakter i sadržaj odluka kojima se oblikuju politike. Države ne misle, one nemaju preferencije i interese. Stavove, preferencije, interese i strasti imaju ljudi. Države stoga nisu akteri nego samo strukture.

"Kritika koju nudi analiza vanjske politike jednostavna je: samo ljudska bića imaju ideje. Samo ljudska bića mogu djelovati na temelju identiteta. Samo ljudi mogu biti socijalizirani i mogu socijalizirati druge. Samo su ljudi akteri u međunarodnim odnosima. Nije riječ o 'idejama od početka do kraja', nego o ljudima kao akterima od početka do kraja, o ljudima koji stoje na čvrstima materijalnim temeljima, šire ideje, uvjeravaju jedni druge u vrijednost tih ideja i pokušavaju ih prenijeti u budućnost kroz procese kao što je institucionalizacija. Kada izbacite ljude iz kalkulacije, kao što su navodno učinili Waltz i Wendt, ostajete samo sa strojem" (Hudson 2014: 12).

Teoretičari međunarodnih odnosa, pa čak i konstruktivisti poput Wendta, zanemaruju važnost analize procesa donošenja odluka. I kada govore o percepcijama i identitetima, važnosti kulture i stvaranja slika o drugome, pogrešno podrazumijevaju da su akteri države. Želi li se razumjeti "ponašanje država" - taj se pojam može koristiti samo uvjetno mora se razumjeti ponašanje onih koji odlučuju u ime država. Stoga se analiza vanjske politike vraća $\mathrm{k}$ proučavanju procesa donošenja odluka, fokusira se na pojedince $\mathrm{i}$ interakciju pojedinaca $\mathrm{u}$ skupinama koje odlučuju, dakle unutar političkih elita, a u međunarodnim od- nosima na komunikaciju među vođama. Međunarodna politika nije zapravo ni politika među narodima ni među državama nego interpersonalna politika politika odnosa među pojedincima koji predstavljaju države.

U Hrvatskoj se analiza vanjske politike prvi put pojavila kao posebno polje interesa u jednom članku Radovana Vukadinovića (1980). Autor najprije prikazuje dileme povezane s mogućnošću stvaranja posebne poddiscipline koja bi se bavila vanjskom politikom. Citira Henryja Kissingera koji je bio skeptičan prema mogućnostima uopćavanja i ekskluzivnosti racionalizma u analizi vanjskopolitičkih odluka. Kissinger je, naime, smatrao da vanjska politika nema svojstva koja joj pridaju istraživačke i obavještajne organizacije, a to su racionalnost i dosljednost: "Jednostavno nisam bio u stanju uvjeriti Francuze da ne postoji takva stvar kao američka vanjska politika i da serija poteza koja je dala određeni rezultat možda nije bila planirana da se postigne upravo takav rezultat" (nav. u: Vukadinović 1980: 159).

Kissingerovo priznanje bilo je dragocjeno vjerojatno upravo zato što je ukazalo na to da se vanjska politika ne vodi nužno nekom teorijskom postavkom ili samo racionalnom računicom. Često je riječ o ad hoc odlukama koje su bile rezultat potrebe da se brzo reagira na događaje. Oblikuje ih kontekst, a formulira reakcija donositelja odluka na licu mjesta, a ne neki dugoročan plan. Pritom su neke odluke pogrešne, jer ljudi često griješe u procjenjivanju i predviđanju, a informacije koje prime procesuiraju u skladu s vlastitim identitetom, selektivno i samo djelomično (Hudson 2014). ${ }^{2}$

\footnotetext{
2 Hudson (2014: 23) zaključuje da analiza vanjske politike osobitu pozornost treba posvetiti psihološkome i socijalnom okruženju koje socijalizira donositelja odluka. "Um donositelja vanjskopolitičkih odluka nije tabula rasa, on sadržava složene i međusobno povezane informacije i modele,
} 
Rezultat nije uvijek ono što se očekivalo zbog niza razloga: zbog loše procjene, opstrukcije u procesu provedbe ili ometanja drugih aktera vanjske politike. Kissingerova izjava mogla je biti potvrda da se $u$ analizi vanjskih politika treba koncentrirati na aktere i procese odlučivanja, na suodnos političkih preferencija i konteksta u kojemu se odluka donosi. ${ }^{3}$

Kissingerova izjava samo je donekle utjecala na Vukadinovića, koji u svojoj definiciji vanjske politike ne spominje pojmove plan ili osmišljenost. On ističe planski i svjestan karakter vanjskih politika socijalističkih zemalja - naročito Lenjinove politike koja se temelji na "za-

kao što su vjerovanja, stavovi, vrijednosti, iskustva, emocije, predodžbe, stil, uspomene, nacionalne i vlastite predrasude". Autorica podsjeća na to da su ljudi nesavršeni kada su posrijedi predviđanja te prihvaćanje i procesuiranje onih informacija koje ne potvrđuju njihove prethodno izgradene stavove.

3 Kissinger je tu tezu razvio u knjizi Treba li Amerika vanjsku politiku (2003). No ostao je realist fokusiran na pitanje vizije i strategije, kao i vrijednosti i ciljeva koje donositelji odluka o američkoj vanjskoj politici moraju uzeti u obzir kada je formuliraju. On smatra da odluke, kolikogod bile reaktivne i spontane, donose akteri koji uglavnom dijele dugoročne vizije, strateške orijentacije i vrijednosti; u protivnom, ne bi se mogli približiti glavnom donositelju odluka koji ih bira kao, primjerice, savjetnike i ministre. Stoga su reaktivnost i brzina odlučivanja ipak podnošljive, jer ne stvaraju nestabilnost i ne vode k propasti. Ipak, Kissinger ne objašnjava što se događa kada neki akteri ili oni koji na njih snažno utječu prestanu dijeliti jednaku viziju ili stratešku orijentaciju. Njihova ad hoc odluka može biti potpuno nepredvidiva, a u maloj skupini donositelja odluka može izazvati sukobe te, u konačnici, raspad države. Primjer poremećaja nastaloga zbog gubitka jedinstvene vizije koju prihvaćaju glavni akteri jesu posljednje godine Jugoslavije. Kissingerov je argument donekle kontroverzan: s jedne strane, prihvaća ad hoc donošenje odluka, a s druge strane govori rječnikom realističke i donekle idealističke teorije. konima neravnomjernog razvitka kapitalističkih zemalja i mogućnosti pobjede socijalizma", kao i na marksizmu kao "analizi društveno-političkih i ekonomskih kretanja na međunarodnoj razini" (Vukadinović 1980: 167-168), koji ujedno nudi i "metodologiju promatranja društvenih pojava" (160) - ali se, ipak, ne suprotstavlja ni Kissingerovu iskrenom priznanju da SAD zapravo nema osmišljenu i planiranu vanjsku politiku. Stoga je "vanjska politika organizirana aktivnost države kojom ona nastoji maksimalizirati svoje vrijednosti i interese u odnosu prema drugim državama i ostalim subjektima koji djeluju u vanjskom okruženju" (Vukadinović 1980: 173-174).

Vukadinovićeva definicija polazi od ekskluzivnog subjektiviteta države kao vanjskopolitičkog aktera, kao u realističkoj teoriji međunarodnih odnosa, ali uključuje i mogućnost participiranja "ostalih subjekata", kao što su međunarodne organizacije, vojno-politički savezi, moćni pojedinci, transnacionalne kompanije i dr. Iako je početkom osamdesetih godina bilo teško zamisliti onakav stupanj integracije alternativnih subjekata u međunarodne odnose kakav je dostigla današnja Europska unija, Vukadinovićeva definicija ostavlja tu mogućnost otvorenom.

Pojam "organizirana aktivnost" nije striktno obligatoran i ne podrazumijeva nužno proaktivan pristup, nego omogućuje i vanjsku politiku koja je pretežno reaktivna. Iako u svojoj definiciji vanjske politike ostaje pritom da je riječ o "aktivnosti države", Vukadinović ističe i važnost analize procesa donošenja odluka te identificira tri nužna elementa uspješne analize vanjske politike:

- analizu aktera i izvršitelja odluka te procesa donošenja odluka kroz interakciju onih koji su $\mathrm{u}$ te procese uključeni; 
- analizu vrijednosti i interesa koje promovira određena vanjska politika. Kombinacija vrijednosti i interesa ukazuje na pokušaj kompromisnog rješenja u sudaru onih koji se oslanjaju na ideologiju kao temelj razumijevanja vanjske politike i onih koji smatraju da se države ponašaju pragmatično, odnosno mnogo realističnije no što im dopušta vlastita ideologija. Iz kompromisne pozicije slijedilo bi da države najčešće nisu samo ni ideološki fanatične ni samo interesno orijentirane. Države imaju i ideologiju i interese pa oboje treba uzeti u obzir u analizi vanjskih politika;

- analizu stanja u međunarodnim odnosima kojom se utvrđuje tko su partneri i saveznici, a tko su suparnici. Države imaju prijatelje, a ne samo interese i ideologije. Kako bi se postigli ciljevi vanjske politike, treba povećati broj prijatelja i smanjiti broj stvarnih ili percipiranih "neprijatelja".

Unatoč značajnom doprinosu studiju vanjske politike u našim okvirima ( $\mathrm{Vu}-$ kadinović 1981, 1989, 2005), autor nikad nije ponudio sustavnu analizu jugoslavenske vanjske politike utemeljenu na pristupu što ga je sam razradio u svojim člancima i knjigama. U ovom članku tim ću se problemom pozabaviti samo "u širokim potezima".

U analizi jugoslavenske vanjske politike oslonit ću se i na druge elemente koji su razvijeni u teorijama vanjske politike što su se smjestile na razmeđi komparativne politike i studija međunarodnih odnosa. Kako je vanjska politika jedna od javnih politika, u obzir treba uzeti i doprinose s područja analize javnih politika. Predmet je ove analize vanjska politika države koja više ne postoji pa sam stoga bio upućen i na historiografiju koja nudi korisne uvide, jer države nasljeđuju svoje legitimne prethodnice, i to ne samo pravno nego i identitetski odnosno kulturalno, čak i onda kada se identitet novih država gradi nasuprot identitetu prethodnih država kao nešto Drugo. Države ne izviru iz ničega nego imaju dugu povijest i bacaju dugu sjenu na svoje moguće sljednice. Uzimajući u obzir sve te elemente, vanjsku politiku Jugoslavije inicijalno treba analizirati u četiri koraka.

Prvo, treba identificirati aktere $\mathrm{u}$ procesu odlučivanja o vanjskoj politici, odnosno donositelje odluka u procesu njezina koncipiranja, prihvaćanja, implementacije i evaluacije. Polazim od teze Hudsonove (2014: 73) da ni u strogo autokratskim režimima vođa nije svemoćan i ne donosi sve odluke sam, bez ikakva konzultiranja sa suradnicima i bez utjecaja informacija kojima je izložen, a koje najčešće stvaraju dijelovi birokratskog aparata (obavještajna zajednica, vojska, informativne službe, partijski aparat i dr.). Osim službenih, postoje i neslužbeni kanali kojima se utječe na vođu kao donositelja odluke, a čine ih obitelj, prijatelji, ponekad i građani posredstvom svojih pisama i izravnih kontakata. ${ }^{4}$

Drugo, treba periodizirati vanjsku politiku Jugoslavije na temelju promjene njezinih prioriteta i glavnih ciljeva. Kao svaka druga javna politika, i vanjska je politika djelomice reaktivna - Kissinger bi rekao da je uglavnom reaktivna - i podložna promjeni osobnosti donositelja odluka ili promjeni sastava skupine koja donosi odluke. Iluzija je da je vanjska politika fiksna, stabilna i, u biti, ne-

4 Da bi se što temeljitije spoznale stvarne osobine vođa koji donose odluke, valja se osloniti na biografije, arhivsko gradivo, studije ličnosti, studije političkog vodstva i druge izvore. U sklopu analize vanjske politike razvila se, naročito u SAD-u, djelatnost profiliranja, koja je bila posebno korištena u obavještajnome i vanjskopolitičkom djelovanju. 
promjenjiva. Jednako je promjenjiva kao i druge javne politike. ${ }^{5}$

Treće, treba odgovoriti na pitanje tko su bili glavni saveznici, a tko glavni suparnici socijalističke Jugoslavije u pojedinim razdobljima. Odatle proizlazi kategorizacija savezničkih i suparničkih zemalja ili skupina zemalja. Jugoslavija je, kao i druge države, na vanjsku politiku gledala i kao na identitetno pitanje. Ona nije samo izražavala preferencije i percepcije drugih država, nego ih je i oblikovala i gradila. Svrstavanje jednih zemalja u prioritetnu, a drugih u manje važnu skupinu, već je akt vanjske politike. Od 1943. do 1992. mijenjali su se prioriteti i percepcije drugih zemalja: Britanija je, primjerice, bila mnogo važnija na početku tog razdoblja, naročito od 1943. do 1946, nego kasnije. S nekim su se zemljama - s Grčkom, Italijom, Austrijom, Njemačkom pa i SAD-om i SSSR-om - odnosi poboljšavali, a s drugima - s Bugarskom, Albanijom, Kinom i dr. - pogoršavali. Previše je pojednostavnjeno i netočno ostati pri uobičajenoj klasifikaciji na "dva vojno-politička bloka". Dinamika vanjske politike socijalističke Jugoslavije pokazuje da je sa zemljama koje su pripadale istom bloku razvijala vrlo različite odnose sukladno tome je li neka zemlja bila percipirana kao prijatelj ili kao netko tko ugrožava državne interese. Tipični su primjeri odnosi s Bugarskom i Albanijom, koje su donekle dijelile jednaku ideologiju s Jugoslavijom, ali su ipak percipirane kao potencijalno neprijateljske države. Hladnoratovske podjele nisu bile apsolutne. ${ }^{6}$

\footnotetext{
5 Primjeri promjena vanjske politike brojni su i u najvećima, a ne samo u manjim državama. Obamina vanjska politika značajno se razlikuje od Bushove i Trumpove, kao i Putinova od Jeljcinove. Primjeri su zaokreta u vanjskoj politici, koji su najčešće povezani sa zaokretima u unutarnjoj politici, suvremena Poljska i Mađarska.

6 I današnja se percepcija Hladnog rata razlikuje od one u vrijeme njegova trajanja.
}

Četvrto, treba identificirati glavne ideje, načela i ciljeve jugoslavenske vanjske politike. To je moguće ponajprije analizom glavnih vanjskopolitičkih govora i aktivnosti Josipa Broza Tita, te članaka i govora njegovih suradnika, ponajviše Edvarda Kardelja. ${ }^{7}$ Kako je riječ o zaokruženom razdoblju koje je završilo prije trideset godina, mogu se koristiti i arhivski dokumenti, makar oni do 1988. Neke sam dokumente koristio i u ovom članku, ponajprije one iz Arhiva Josipa Broza Tita koji je sada sastavni dio Arhiva Jugoslavije u Beogradu.

U nastavku ću se usredotočiti na prvu od četiriju navedenih tema - na odnose aktera i struktura u procesu odlučivanja o vanjskoj politici socijalističke Jugoslavije. Pokušat ću rekonstruirati način odlučivanja na temelju memoarske i arhivske građe. Pokazat ću da je u cijelom razdoblju svoga vladanja Tito bio glavni, ali ne i jedini donositelj odluka o vanjskoj politici. Čak i u prvom razdoblju, kada je njegova moć bila veća nego pri kraju života, o vanjskoj politici odlučivali su i drugi akteri: članovi kabineta predsjednika vlade odnosno Kancelarije maršala Jugoslavije (od 1953. Kabineta Predsjednika Republike), državni odnosno Savezni sekretarijat za inozemne poslove, posebno kolegij ministara koji

Analiza Titovih i Kardeljevih govora i članaka pokazuje da oni već krajem šezdesetih godina govore o Hladnom ratu kao o prošlosti, smatrajući pod tim pojmom uglavnom razdoblje berlinske i kubanske krize. Detant ne smatraju hladnoratovskim razdobljem. Danas se pod Hladnim ratom razumije razdoblje od 1949. do 1989.

7 Analiza vanjske politike razvija metodologiju i instrumente analize diskursa, i to kvantitativne (brojanje riječi i fraza koje vođe koriste u svojim govorima) i kvalitativne (analiza verbalnoga ili neverbalnog sadržaja, kao što su simboli, geste i dr.). Unutar tih istraživačkih programa razvijaju se računalni programi kako bi komparacije vanjskih politika bile što preciznije (Hudson 2014). 
je okupljao čelnike ministarstava, protokolarna služba, analitičke službe raznih ministarstava, članovi državnoga i partijskog vrha. $\mathrm{S}$ vremenom se proces odlučivanja institucionalizirao, pa su povremeno izbijale nesuglasice među pojedinim akterima, posebno među Saveznim sekretarijatom za inozemne poslove i partijskim vrhom. U posljednjih deset godina Titova života i poslije formiranja Predsjedništva SFRJ 1971. odluke o vanjskoj politici donosile su se u komunikaciji Predsjednika Republike i Predsjedništva SFRJ. Kao akteri u tom procesu sudjeluju i republike i pokrajine, kako posredstvom svojih predstavnika u saveznim institucijama tako i posredstvom diplomacije i službi vanjskih poslova te novoformiranih komiteta za suradnju s inozemstvom pri republičkima i pokrajinskim vladama. U zaključnom dijelu ukratko ću evaulirati jugoslavensku vanjsku politiku iz perspektive raspada države.

\section{Akteri i strukture u jugoslavenskoj vanjskoj politici}

Odnos aktera i struktura jedno je od temeljnih pitanja i u analizi vanjske politike i u teorijama međunarodnih odnosa i društvenim znanostima općenito. Države se pojavljuju u dvostrukoj ulozi: u domaćoj politici one su strukture, a ne akteri, a u međunarodnim odnosima još se pretežno tretiraju kao akteri, iako analitičari vanjskih politika smatraju da "države nisu akteri, jer su države apstrakcije koje nemaju u sebi svojstvo aktera" (Hudson 2007: 6). U biti, analiza vanjske politike bavi se stvarnim akterima koji odlučuju. Neorealistička teorija međunarodnih odnosa smatra da se države "ponašaju" ovisno o karakteru strukture međunarodnog sustava, uzimajući državu kao aktera po sebi. Carlsneas ukazuje na razliku između neorealizma i neoklasičnog realizma koji se, vraćajući se Morgenthauovu klasičnom realizmu, vraća i psihologističkim elementima koje je on razvijao u svojima, ponajprije ranim, radovima te zaključuje da je neoklasični realizam bliži analizama vanjske politike zbog tretiranja ljudi kao aktera. Neoklasični realizam još smatra da vanjsku politiku neke zemlje "primarno oblikuje njezino mjesto u međunarodnom sustavu, a posebno sposobnost da upotrijebi svoju stvarnu moć". No "ti teoretičari istodobno tvrde da je utjecaj sistemskih faktora na vanjsku politiku pojedine zemlje samo neizravan i složeniji nego što neorealisti pretpostavljaju, budući da te osobine mogu utjecati na donošenje odluka samo posredstvom faktora domaće politike" (Carlsneas 2012: 120).

Carlsneas (2012: 117) je dvojnost o tome tko su akteri riješio zaključujući da "akteri dominiraju na nižoj razini analize (na razini individualnoga ili grupnog donošenja odluka), dok su strukture važnije kada razina postane viša i općenitija, odnosno apstraktnija (a naročito na razini međunarodne politike). Stoga razvija shemu za analizu vanjske politike koja uključuje sljedeće elemente: (1) strukturnu dimenziju, od koje se polazi i koja utječe na (2) stvarnost, te akteri tako formiraju (3) namjere, a to na kraju rezultira pokretanjem neke (4) vanjskopolitičke akcije. Rosenau (1966), jedan od utemeljitelja analize vanjske politike, smatra da treba konstruirati "teoriju srednje razine" između opće teorije i stvarnosti, dok Putnam (1988) govori o "igri na dvjema razinama", domaćoj i vanjskoj. Svaka razina ima svoja pravila, a akteri traže načine da ih pomire ili makar da spriječe njihovu potpunu neusklađenost.

Pitanjem odnosa aktera i struktura bavila se i Marina Ilić (2016) u sklopu rasprave o konstruktivističkim teorijama međunarodnih odnosa. Konstruktivistički pristup fokusira se na oblikovanje percepcija i važnost identiteta te je stoga kritički prema neorealizmu 
i teoriji svjetskog sustava (Wallerstein 1974). No i konstruktivisti gledaju na države kao na aktere, kao da one gledaju, misle i odlučuju. Zagovornici analize vanjske politike smatraju da je tretiranje država kao aktera izvor nepomirljivih prijepora koji dovode $\mathrm{u}$ pitanje njihovu upotrebljivost, ali i akademsku vjerodostojnost. Ilić (2016: 149) misli da se prijepori mogu nadvladati strukturacionom teorijom koja "vidi agenta i strukturu kao ontološki različite, ali ravnopravne i neodvojive entitete koji su međusobno uslovljeni i zavisni". Autorica ističe da Wendt, jedan od vodećih konstruktivista, ${ }^{8}$ razvija interpretaciju koja na odnos aktera i strukture gleda kao na odnos suuspostavljanja pa "nema agenta bez strukture, niti ima strukture bez agenta". Suprotstavljajući individualni i strukturni pristup u teorijama međunarodnih odnosa, Ilić razlikuje Morgenthauov od Waltzova realizma. Morgenthau, okrenut istraživanju izvora želje za moći i emocijama, kao što je strah, opet je postao aktualan $\mathrm{u}$ analizi ponašanja pojedinih političkih vođa i drugih aktera. Istodobno, strukturalizam, što priznaje i sam Waltz, nije potpuno upotrebljiv $u$ analizi procesa odlučivanja unutar države, a time ni kao sredstvo objašnjavanja motiva i uzroka pojedine odluke. Iako je Waltz cijelu svoju teoriju gradio na ideji o tri razine, odnosno o tri imaga ili tri slike - pojedinačnoj, državnoj i sistemskoj - njegovo se djelo uglavnom usredotočuje na odnos države kao jedinice $\mathrm{i}$ međunarodnog sustava kao strukture. ${ }^{9}$ Nasuprot tome, analizu vanjske politike najviše zaokupljaju odnosi pojedinca i države te pojedinca i međunarodnog sustava.

8 O konstruktivističkim teorijama međunarodnih odnosa v. Wendt 2014; Zehfuss 2002; Jović 2016.

9 O Waltzovu neorealizmu v. Waltz 2001, 2008, 2008a; Keohane 1986; Novičić 2009; Mearsheimer 2013.
Što ti pristupi govore o vanjskoj politici socijalističke Jugoslavije? Odgovor na to pitanje ovisi o tome jesmo li primarno strukturalisti ili individualisti, to jest jesmo li bliži strukturnim teorijama međunarodnih odnosa ili pristašama analiza vanjske politike.

Ako mislimo da ponašanje države $u$ međunarodnim odnosima oblikuje ponajprije struktura međunarodnih odnosa, koncentrirat ćemo se na međunarodne okolnosti: karakter i ishod Drugoga svjetskog rata, poslijeratni poredak u Europi, položaj Jugoslavije u Europi i posebno na Balkanu, karakter Hladnog rata. Posebno je važna 1948. kao prekretnica u odnosu Jugoslavije prema SSSR-u. Strukturni pristup naglašava važnost izvanjskih događaja koji su, neovisno o volji jugoslavenskih vođa, formirali strukturu, koja je potom odredila karakter vanjske politike Jugoslavije, a u konačnici i njezinu sudbinu. Strukturni pristup doveo bi do zaključka da je Tito praktično morao odgovarati na promjene koje su oblikovali moćniji akteri međunarodne politike (primjerice, Staljin, a prije njega "velika trojka" Staljin-Churchill-Roosevelt), htio to ili ne. Vanjska politika Jugoslavije stoga bi bila uglavnom reaktivna. Strukturni pristup objasnio bi raspad Jugoslavije poglavito pomoću dvaju ključnih događaja s kraja Hladnog rata. Prvi je bio slom međunarodnog sustava koji je oblikovan u Hladnom ratu i potvrđen helsinškim dokumentima sedamdesetih godina. Drugi je preoblikovanje Europe iz bipolarnoga međunarodnog sustava u unipolarnu međunarodnu organizaciju sui generis koja ima ambiciju promijeniti karakter svih europskih država i potom ih asimilirati u jednu Europu. Ta dva događaja značajno su promijenila strukturu međunarodnog poretka i tako uzdrmala jugoslavensku vanjsku politiku. Nesvrstanost je moguć odgovor na bipolarnost, ali ne i na unipolarnost. Kratko 
razdoblje kaosa i anarhije neposredno nakon kraja Hladnog rata, od pada Berlinskog zida 1989. do dogovora o novoj Europi u Maastrichtu 1992, stvorilo je u Jugoslaviji hobsijansko stanje u kojemu je počeo rat svih protiv sviju. Oba Kissingerova upozorenja - ono o stalnoj važnosti realizma i ono o važnosti "vizija i strategija" utemeljenih na zajedničkim vrijednostima i uvjerenjima - pokazala su se opravdanima.

Strukturni pristup bio bi primjenjiv i kada bi se kao glavni akteri postavile republike i pokrajine, a Jugoslavija se tretirala kao struktura, neka vrsta kvazimeđunarodnog poretka koji je oblikovao ponašanje republika i pokrajina kao aktera. Kao što je slom međunarodnog poretka kao strukture omogućio kaos i anarhiju u kojoj se raspala Jugoslavija, tako je slom Jugoslavije kao nadnacionalne strukture stvorio kaos i anarhiju u kojima su se privremeno raspale Hrvatska, Bosna i Hercegovina, Srbija i Kosovo. Strukturalisti bi tom pitanju prišli s pozicije koja smatra da političke vođe gotovo ništa nisu mogli učiniti u tim okolnostima, jer je snaga strukturnih promjena bila tolika da bi se svaki vođa u sličnima ili jednakim okolnostima ponašao slično ili jednako. Njihova prethodna uvjerenja nisu imala ključnu važnost: od uvjerenih internacionalista "preko noći" postali su nacionalisti, jer se promijenila struktura međunarodnih odnosa te je internacionalizam postao nemogućim, a nacionalizam nužnim. Ako su htjeli opstati kao politički akteri, morali su odbaciti dotadašnji sustav vrijednosti i politički sustav te prihvatiti nove vrijednosti i novi sustav ili makar simulirati da su ih prihvatili. Vanjska politika u unipolarnom poretku ograničena je kontekstom u kojemu se za neku opciju (pridruživanje Zapadu, europeizacija, politička pluralizacija) tvrdi da je postala "jedina mogućnost" kojoj "nema alternative". Ona je nalik na vo- žnju bobom: postoji samo jedno korito, ne može se skrenuti ni lijevo ni desno, može se samo prevrnuti i ostati na pola puta. Subjektivnost je minimalna, a uspjeh je zajamčen ako se slijede trendovi u međunarodnoj strukturi. Onima koji se suprotstavljaju tim trendovima prijeti opasnost da budu izolirani ili proglašeni problematičnim državama na koje treba primijeniti pritisak ili silu.

Nasuprot tome, individualizam ističe važnost pojedinaca, najčešće političkih vođa, kao glavnih aktera svih političkih procesa. Tako se Titova odluka da odbaci Staljinove zahtjeve 1948. vidi kao tipičan slučaj koji potvrđuje tezu da odlučuju samo pojedinci. Da je taj pojedinac, politički vođa, drugačije percipirao ciljeve, da je drugačije procijenio snagu otpora s kojim se suočava, da je bio drugačijeg karaktera, da je imao drugačije psihološke i kognitivne osobine, vanjska politika Jugoslavije bila bi drugačija. To se odnosi i na procjene o kasnijem okretanju k nesvrstanima koje je, doduše, bilo moguće samo zato što su već bila uspostavljena dva vojno-politička saveza, ali nije bio izraz sistemski uvjetovane nužnosti nego svjesne vanjskopolitičke odluke. Zagovornici analize vanjske politike ističu i značenje Titove ličnosti pa u periodizaciji jugoslavenske političke povijesti zatvaraju jedno i otvaraju novo razdoblje s njegovom smrću 1980. Raspad Jugoslavije objašnjavaju ponašanjem ključnih političkih ličnosti: dogmatizmom i neprilagodljivošću članova staroga socijalističkog političkog vrha, karakterom Slobodana Miloševića, a potom i Milana Kučana, Stipe Šuvara, Franje Tuđmana, Veljka Kadijevića i drugih aktera. Da su političke vođe iz osamdesetih godina bili više nalik na Václava Havela, a ne imitacija Josipa Broza Tita u novima, strukturno ograničavajućim okolnostima, ishod politike bio bi drugačiji. Da se u SSSR-u nije pojavio Mihail Gorbačov, možda 
bi Hladni rat još trajao. Zagovornicima analize vanjske politike presudna je uloga ličnosti, pri čemu se analizira i interakcija ključnih ličnosti: dinamika odnosa u manjima odlučivačkim skupinama, kao što su bili Predsjedništvo SFRJ i Predsjedništvo CK SKJ; odnos pojedinih dijelova državne administracije, primjerice Saveznog sekretarijata za inozemne poslove i partijskoga i vojnog vrha, obavještajne zajednice i političkog vrha ili političkih vodstava republika i pokrajina; utjecaj drugih aktera na proces odlučivanja, primjerice medija, civilnog društva, poslovne elite i dr.; ideje, vrijednosti i načini na koje su akteri interpretirali događaje u domaćoj i međunarodnoj politici.

Tito je bio najutjecajniji akter u kreiranju jugoslavenske vanjske politike i kao premijer (1945-1953) i kao Predsjednik Republike (1953-1980). Vanjska i sigurnosna politike bile su njegova "rezervirana područja" koja je želio potpuno kontrolirati. Kojigod od dvaju pristupa slijedili, treba temeljito analizirati njegova vjerovanja, percepcije, karakter, emotivne i kognitivne aspekte njegova načina odlučivanja, ali takva analiza nadilazi granice ovog članka.

U analizama formiranja vanjske politike Jugoslavije uobičajena je tvrdnja kako je o njoj odlučivao jedan čovjek Josip Broz Tito. No na oblikovanje vanjske politike utjecali su i drugi akteri: državni i partijski vrh (članovi kolektivnih tijela koji su upravljali partijom i državom, članovi vlade), savezni sekretari za vanjske poslove, veleposlanici, državni protokol, obavještajne i stručne službe. Njihov se utjecaj s vremenom povećavao. Budimir Lončar, koji je u jugoslavenskoj diplomaciji bio od 1949, tvrdi da je u ratnome i neposrednom poslijeratnom razdoblju (1941-1948) Tito vodio vanjsku politiku uglavnom samostalno, "uz pomoć najbližih suradnika" Edvarda Kardelja, Milovana Đilasa i Vladimira
Velebita. ${ }^{10} \mathrm{U}$ tom razdoblju Lončar identificira dva glavna cilja vanjske politike: (1) stjecanje međunarodnog priznanja Jugoslavije i (2) inkorporiranje teritorija na kojima su u susjednim zemljama živjeli pripadnici jugoslavenskih naroda u sastav Jugoslavije. U postizanju prvog cilja ključan je bio odnos s Ujedinjenim Kraljevstvom koje je trebalo uvjeriti u to da politika povratka na status quo ante okupacije zemlje ne znači i povratak monarhije.

Stanje se značajno mijenja nakon 1948. Kako bi izbjegao ozbiljnije izazove u užem krugu svojih suradnika, Tito odlučuje formalizirati proces odlučivanja te se u donošenju ključnih odluka konzultira s Politbirom CK KPJ. O odgovoru na Staljinovo pismo - prvu verziju napisao je, kako je vidljivo iz arhivske građe, sam Tito - raspravljalo se na sastanku Politbiroa, što je tipičan primjer odlučivanja u maloj zatvorenoj skupini. Uključivanje drugih aktera $\mathrm{u}$ proces odlučivanja dovelo je do oblikovanja državnoga odnosno Saveznog sekretarijata za inozemne poslove kao donekle posebne državne institucije. Naime, kako bi se država što bolje predstavljala u drugim zemljama, Tito je vrata te institucije otvorio i onima koji nisu bili ideološki rigidni komunisti. Prvi poslijeratni jugoslavenski veleposlanici bili su uglavnom diplomati građanske orijentacije, kao što su Sava Kosanović (u SAD-u), Stanoje Simić (u SSSR-u) i Ljubo Leontić (u Velikoj Britaniji). Od ostalih istaknutih diplomata socijalističke Jugoslavije koji su počeli karijeru kao diplomati građanske orijentacije treba istaknuti Radu Pribićevića (u Poljskoj), Marka Ristića (u Francuskoj), Milana Ristića (u Švicarskoj i Egiptu), Božina Simića (u Turskoj), Izidora Cankara (u Grčkoj), Vladimira Ribarža (u Norveškoj), Miloša Moskovljevića (u Norveš-

\footnotetext{
10 Intervju autora s Budimirom Lončarom, 23. siječnja 2018. u Zagrebu.
} 
koj i Egiptu), te Darka Černeja (u Meksiku i Francuskoj). ${ }^{11}$

Poslije 1948. donekle su se promijenili karakter i profil diplomatske službe, ali ona je ostala - naročito dok je državni sekretar bio Koča Popović (1953-1965) - otvorenijom i nedogmatičnijom od partije. Između partijskih tijela i vanjskopolitičkih institucija česte su bile razlike, pa i politički sukobi (Žarković 2017). Djelomice je to bio sukob ličnosti, ponajviše Koče Popovića i Edvarda Kardelja, koji je imao i političku dimenziju. Kardelj je bio više partijski ideolog koji se brinuo za ideološki smjer vanjske politike, dok je Popović htio uspostaviti profesionalnu diplomaciju i zaštititi ministarstvo vanjskih poslova od prevelikog utjecaja partijskih kadrovika i obavještajnih službi. Popović je nastojao da to ministarstvo postane sukreator odluka onoliko koliko je to moguće u sustavu u kojemu je Tito bio najmoćniji akter. Pritom je koristio i Titov ego tako što ga je diplomatska mreža ministarstva promovirala u svjetskog vođu. ${ }^{12}$ Pripremni materijali za sastanke sa stranim državnicima bili su sredstvo utjecaja na Tita. Istodobno, partijski vrh i obavještajna zajednica upozoravali su na "partijska skretanja" i sigurnosne rizike u diplomatskoj službi. Među "skretanjima" najčešće se spominjao "antisovjetizam", jer se znalo da on Titu, unatoč raskidu sa SSSR-om, nije bio blizak. Sukob tih dviju skupina eskalirao je krajem šezdesetih i sedamdesetih godina nakon odlaska Koče Popovića, kojega su nakrat-

${ }_{11}$ O jugoslavenskoj diplomaciji od 1945. do 1950. v. Selinić (2014).

12 O elementima Titova egoizma, a donekle i grandomanije v. Kissingerov pripremni materijal za posjet Nixona Jugoslaviji (Batović 2017: 146-148). Čini se da je s godinama Tito bio sve skloniji isticati svoju iznimnost, što je ponekad izazivalo podsmijeh i kritiku i u političkom vrhu. Tipičan je primjer bio njegov stil odijevanja na proslavi dva i pol tisućljeća Perzijskog Carstva u Teheranu 1971. ko naslijedili relativno liberalni savezni sekretari Marko Nikezić (1965-1968) i Mirko Tepavac (1969-1972).

Akteri koji su odlučivali o jugoslavenskoj vanjskoj politici ponekad nisu bili dovoljno koordinirani (Vukadinović 1988), a ponekad su se i politički razilazili, uglavnom skriveno od javnosti, sve dok sjednice CK SKJ nije počela prenositi televizija krajem osamdesetih godina. Žarković (2017) prikazuje glavne točke prijepora u raspravama o odnosu prema SSSR-u 1962. i 1963. ${ }^{13}$ Vukadinović (1988: 3) navodi i razlike o tome "da li priznati i Južnu Koreju, kako i kada uspostaviti odnose s Izraelom, ili kako se približiti Evropskom vijeću". Najveću krizu uzrokovao je arapsko-izraelski rat 1967. Batović (2017: 120) navodi da je tada postala "jasna razlika između ministarstva vanjskih poslova, koje je predvodio Marko Nikezić, i Titova kabineta". Liberalnija struja u službi vanjskih po-

13 Iz Žarkovićeve analize proizlazi da donositelji odluka nisu bili jedinstveni čak ni šezdesetih godina. Glavni akteri koji su se borili za utjecaj na oblikovanje vanjske politike bili su: "sipovci" (funkcionari Saveznog sekretarijata za inozemne poslove), partijski funkcionari, funkcionari obavještajnog sustava te bivši i aktualni ambasadori. Žarković prikazuje sukobe dviju struja formiranih početkom šezdesetih godina: jednu su predvodili Tito i Aleksandar Ranković, a drugu Edvard Kardelj i Koča Popović. Prva struja zamjerala je drugoj pretjerano kritički odnos prema SSSR-u i previše popustljiv prema SAD-u. Na površini toga dubinskog sukoba događale su se razne afere (primjerice, smjena veleposlanika u Sofiji Predraga Ajtića). Odnos prema SSSR-u u cijelome poslijeratnom razdoblju bio je ključno pitanje jugoslavenske vanjske politike. Tito ga je držao svojim privilegiranim područjem, odlučujući često sam i suprotno volji mnogih u partijskome i državnom vrhu. Pritom je, kako je rekao ministar vanjskih poslova Mirko Tepavac, "robovao sopstvenom ideološkom obrazovanju" (nav. u: Žarković 2017: 111). O odnosima KPJ i jugoslavenske diplomacije u prvim godinama nakon preokreta (19451952) v. i Selinić 2013. 
slova, koju je podržavao i tadašnji potpredsjednik Jugoslavije Koča Popović, kritički je gledala na Titovu bezuvjetnu podršku arapskim zemljama, a naročito na njegovo približavanje SSSR-u u tom pitanju. Batović (2017: 121) navodi kako tada "prvi put javno mnijenje pokazuje znakove neslaganja sa službenom vanjskom politikom", koje je bilo uzrokovano i generacijskom razlikom. Nova generacija u ministarstvu bila je okrenuta Zapadu, dok je starija favorizirala nastavak politike nesvrstanosti koja je uključivala i bliskost s arapskim zemljama. Razlike su bile očite i u odnosu prema SSSR-u prema kojemu je Tito gajio odredene sentimente povezane s njegovom revolucionarnom prošlošću. Da nije bilo sovjetske okupacije Čehoslovačke 1968, možda bi se razlike produbile. No Titova kritika sovjetske intervencije, a potom i novo približavanje SAD-u koje je dovelo i do Nixonova posjeta Jugoslaviji 1971, spriječili su ozbiljnije razilaženje. Ipak, u političkoj čistki koja je uslijedila protiv "srpskih liberala" 1972. iz politike su otišli što vlastitom voljom, a što Titovom odlukom, trojica nekadašnjih čelnih ljudi ministarstva vanjskih poslova: Koča Popović, Mirko Tepavac i Marko Nikezić.

Iako je bio glavni donositelj odluka, Tito je uvažavao i mišljenja diplomatske službe prema kojoj se odnosio s poštovanjem. To se naročito odnosi na prve poslijeratne diplomate koji su, iako nisu imali iskustva u diplomatskoj ili nekoj drugoj državnoj službi, brzo učili te su impresionirali obrazovanošću, razumnošću i galantnošću. Aleš Bebler, Jože Brilej, Srđa Prica, Veljko Mićunović, Ljubo Leontić, Ivo Vejvoda, Leo Mates i osobito Vladimir Velebit bili su od goleme koristi Titovoj vanjskoj politici. Iz bilježaka na marginama telegrama i drugih dopisa koje je svakodnevno dobivao od diplomata, očito je da je Tito njihove izvještaje pažljivo čitao i da je bio sklon poslušati njihove savjete. Na njegove odluke utjecale su i analitičke službe Saveznog sekretarijata za inozemne poslove koje su pripremale, i opsegom i sadržajem, često fascinantne materijale za Titove posjete drugim zemljama i prijeme stranih državnika. Obrazac za pisanje izvještaja imao je desetak poglavlja - u praksi ponekad i deset arhivskih kutija, označenih od 01 do 10 - koja su sadržavala podatke i analitičke ocjene o unutarnjoj politici respektivne zemlje, njezinu ekonomskom razvoju, bilateralnim odnosima s drugim zemljama, multilateralnoj aktivnosti, ličnostima koje bi se susrele s Titom, prethodnim sastancima i glavnim zaključcima, javnima i polujavnim istupima glavnih političara u toj zemlji te o pitanjima koja bi druga strana mogla postaviti u razgovorima. Neki izvještaji uključivali su i sigurnosne procjene: podatke o neprijateljskoj političkoj emigraciji i drugim izvorima mogućih rizika. Program posjeta i protokolarne pojedinosti bili su samo jedna od deset tema o kojima su administrativne službe vodile računa.

Katkad bi analitički materijali bili prave knjige. Primjerice, za posjet britanskog ministra vanjskih poslova Anthonyja Edena 1952. pripremni je materijal imao 258 stranica, a najveći je materijal pripremljen za posjet sovjetske delegacije, koju je predvodio Nikita Hruščov, Beogradu 1955. Osim toga, analitičke službe i kabinet Predsjednika Republike pripremali su i informacije o pisanju medija, a jugoslavenske su ambasade često slale odlične koncizne analitičke izvještaje koje je Tito obično čitao, što je vidljivo iz bilješki na marginama.

Lončar opisuje odnos Tita i Saveznog sekretarijata za inozemne poslove kao stalnu interakciju, koja podsjeća na konstruktivističku ideju suuspostavljanja aktera $i$ struktura. Ponekad bi sam Tito odlučio sudjelovati na nekoj međuna- 
rodnoj konferenciji ili posjetiti neku zemlju, a ponekad bi to činio na inicijativu Saveznog sekretarijata. Kolegij Saveznog sekretarijata, koji su činili savezni sekretar, njegov zamjenik, pomoćnici i načelnici pojedinih odjela i službi, raspravljao bi o platformi za posjet, koja bi potom bila predstavljena Titu kako bi je komentirao i odobrio. ${ }^{14} \mathrm{U}$ proces bi se uključila i Grupa za analizu i planiranje (GAP), kojoj je Lončar bio na čelu od 1957. do 1964. Ona je bila zadužena za analitičku pripremu vanjskopolitičkog događaja, a koordinirala je i rad jugoslavenskih ambasada dajući im orijentacijske upute svakih deset dana, katkad i češće. GAP je objedinjavao obavještajne i diplomatske informacije i bio je izravno vezan za saveznog sekretara. Veće događaje, kao što su bile konferencije nesvrstanih, pripremao je nacionalni odbor u kojemu su sudjelovali političke vođe, ali i predstavnici državne administracije, lokalnih samouprava i tehničko osoblje. Za takve događaje Savezni sekretarijat također bi pripremao platformu. $U$ formaliziranju procedura odlučivanja, kao i u uključenosti cijelih ministarstava, očiti su elementi birokratizacije, odnosno strukturiranja procesa odlučivanja. Ipak, on je ostao vrlo personaliziran, osobito iz perspektive suvremenih demokratskih

14 Budimir Lončar se prisjeća da su postojale tri vrste kolegija u ministarstvu: 1) formalni kolegij saveznog sekretara koji su činili zamjenik sekretara, podsekretari i pomoćnici sekretara, 2) "uži kolegij" u kojem su bili samo savezni sekretar, zamjenik, te načelnik GAP-a, 3) "širi kolegij" u koji su se pozivali i predstavnici uprava u ministarstvu, ovisno o temi o kojoj se razgovaralo. Kasnije, osamdesetih godina, jednom mjesečno ili jednom u dva mjeseca, ovisno o potrebi, sazivao se i kolegij saveznog sekretara s predsjednicima republičkih i pokrajinskih komiteta za inozemne poslove, posebno kada se radilo o pitanjima odnosa sa susjedima, statusu manjina i pitanjima povezanima s "radnicima na privremenom radu u inozemstvu" (gastarbajterima). Razgovor autora s Budimirom Lončarom, 15. ožujka 2018. u Zagrebu. standarda, a Titovi osobni prijatelji i najbliži suradnici imali su izravan pristup i velik utjecaj na njega zahvaljujući zajedničkoj prošlosti, ponajprije sudjelovanju u partizanskoj borbi. Utjecaji tih neformalnih kanala ponekad su bili suprotstavljeni. Tako su, prema Lončarovu svjedočenju, na jednoj strani bili - u raznim razdobljima - Aleksandar Ranković, Edvard Kardelj, Dobrivoje Vidić, partijski sekretari u Saveznom sekretarijatu za inozemne poslove i dr., a na drugoj Koča Popović, Veljko Mićunović, Antun Vratuša, Miloš Minić, Aleksandar Grličkov (potonja dvojica iz partijskog aparata, a Minić kasnije i kao savezni sekretar za inozemne poslove) i dr. Nasuprot pojednostavnjenim interpretacijama koje zanemaruju unutarnju dinamiku i ograničeni pluralizam u autoritarnim sustavima, dokumenti i svjedočenja o procesu odlučivanja o jugoslavenskoj vanjskoj politici pokazuju da su odluke bile personalizirane, ali i da su na njih utjecali mnogi akteri koje je Tito uvažavao, a ponekad je zbog njih mijenjao svoju prvobitnu odluku.

To se češće događalo u kasnijoj fazi Titove vladavine kada je proces odlučivanja bio formaliziran, a posebno nakon što je formirano Predsjedništvo SFRJ. Formaliziranje procedure, koje je uključivalo raspravu u kojoj su sudjelovali i resorni ministri, omogućilo je da se čuju stajališta i posebni zahtjevi predstavnika republika i pokrajina. Zapisnici s nekih pripremnih sastanaka, primjerice zapisnik sa sastanka uoči Titova posjeta Švedskoj od 29. ožujka do 1. travnja 1976, pokazuju da nije uvijek bilo suglasja o glavnim pitanjima. Na sjednici Predsjedništva SFRJ 27. ožujka 1976. raspravljalo se o tome treba li posjet Švedskoj odgoditi s obzirom na to da je prethodnog dana švedska državna televizija emitirala "antijugoslavensku emisiju" te da su, prema izvještaju saveznog sekretara za unutarnje poslove Franje Herljevi- 
ća, održane "prohrvatske demonstracije" koje je predvodio Branko Salaj. ${ }^{15}$ Tito je na početku rasprave rekao da je skloniji odgađanju posjeta, i to ne samo zbog posljednjih događaja, nego zbog kontinuiteta švedske politike prema "neprijateljskoj emigraciji": demonstracija, napada na diplomatske predstavnike, uključujući ubojstvo jugoslavenskog ambasadora u Stockholmu Vladimira Rolovića u travnju 1971, otmice švedskog zrakoplova 1972. kako bi se pustio iz zatvora Rolovićev ubojica Miro Barešić. Unatoč Titovu inicijalnom stavu, ministar vanjskih poslova Miloš Minić zauzeo se za to da se posjet ne odgađa i ne otkazuje. Istaknuo je da u Švedskoj radi oko 40.000 jugoslavenskih radnika i da bi otkazivanje posjeta poslalo pogrešnu poruku kako se Jugoslavija uplašila. Iznio je podatak da je u prethodnim demonstracijama sudjelovalo samo 150 emigranata, a očekivalo se da će ih biti oko tri tisuće. Minić je rekao da treba podržati vanjsku politiku švedskog premijera Olofa Palmea, koji se također izlaže stanovitom riziku pozivajući Tita u Švedsku. Minićeva rasprava bila je primjer neslaganja s Titom i Herljevićem. Na Herljevićevoj strani bili su Stane Dolanc i članovi Predsjedništva SFRJ Vidoje Žarković i Stevan Doronjski. Herljević je pak kazao da će švedska policija biti izrazito oprezna i da će potpuno okružiti Tita, što će stvoriti dojam da je ugrožen, a to nije dobra poruka. Rekao je da švedska policija materijalno i politički zapravo pomaže antijugoslavenskim grupama, navodeći kako je to jedan od mogućih razloga ubojstva ambasadora Rolovića. ${ }^{16} \mathrm{Na}$ prijedlog Miloša

15 V. Zapisnik sjednice Predsjedništva SFRJ ( KPR I-II/1971, Švedska, u Arhivu Josipa Broza Tita, sada u Arhivu Jugoslavije).

$16 \mathrm{U}$ pripremnom materijalu za taj posjet navodi se da je u Švedskoj živjelo 1.100 političkih emigranata. Poseban problem bilo je društvo Matija Gubec, a kao predvodnici neprijateljske emigracije istaknuti su Franjo Mikulić, koji je ubijen u Njemačkoj 1983, i svećenik Vjekoslav Lasić.
Minića zaključeno je da se jugoslavenskom ambasadoru u Švedskoj Feliksu Gorskom pošalju instrukcije da bi hitno obavijestio Palmeov ured da Tito razmatra odgađanje posjeta kako bi se Švedska prisilila da se jasno odredi prema neprijateljskoj emigraciji. To je i učinjeno pa je Predsjedništvo odlučilo da Tito ipak ide na put.

Taj zapisnik pokazuje da se proces donošenja vanjskopolitičkih odluka s vremenom donekle formalizirao i da su u njemu sudjelovali mnogi akteri. Konačnu je odluku donosio Tito, ali je bio spreman promijeniti mišljenje nakon prilično slobodne rasprave. Zapravo, Tito je još od početka šezdesetih godina morao voditi računa o drugim akterima i na horizontalnoj i na vertikalnoj razini. $\mathrm{Na}$ razini federacije pojavili su se novi akteri koji su htjeli izgraditi samostalnu poziciju ili su se natjecali za Titova nasljednika, kao Aleksandar Ranković i Edvard Kardelj. Sedamdesetih godina ključno "paralelno" tijelo koje je utjecalo na vanjsku politiku bilo je Predsjedništvo SFRJ. Ono je bilo paralelan kolektivni šef države, što je bio presedan u međunarodnim razmjerima, a uspostavljeno je kako bi se osigurala mirnija tranzicija u posttitovskom razdoblju. Značajna uloga Predsjedništva vidljiva je, primjerice, iz činjenica da je ono odlučivalo o sastavu delegacija koje bi Tito predvodio u posjetima stranim zemljama. Prvi je put Predsjedništvo odlučivalo o Titovu posjetu SSSR-u od 5. do 10. lipnja $1972 .{ }^{17}$ Tito je zadržao pravo

\footnotetext{
17 Taj je posjet proceduralno značajan i zato što je pripremni sastanak održan u kabinetu Veljka Vlahovića 15. svibnja 1972, a ne u Titovu kabinetu. Vlahović je u to doba bio samo partijski, a ne i državni funkcionar. U dokumentima koji su pohranjeni u Arhivu Jugoslavije piše da je "od strane drugarice Broz dana primedba da u pratnji ne bi trebalo da budu lični sekretar Slavko Popović i lekar dr. Slobodan Milojković". Tito je izbacio iz delegacije liječnika, ali je ostavio Popovića. Taj detalj pokazuje da
} 
veta na sastav delegacije, ali ga je više koristio kada su posrijedi bili njegova supruga Jovanka Broz, osobni liječnici i drugi pomoćni članovi delegacije nego političke ličnosti.

Na vertikalnoj razini, vodilo se računa o stavovima republika i pokrajina koje su postajale sve utjecajniji akteri mnogih javnih politika, a djelomice i vanjske politike, kao što su to bile Slovenija i Makedonija, ${ }^{18}$ a o pitanju međunarodne trgovine i devizne politike i Hrvatska. I vanjska je politika evoluirala: od prilično centraliziranog sustava na početku socijalističkog razdoblja prema supstancijalno federalističkom sustavu sedamdesetih godina. Iako je vanjska politika ostala primarna nadležnost federacije, prema Ustavima 1963. i 1974. i republike i autonomne pokrajine postale su ak-

je i Titova supruga imala ili je htjela imati određen utjecaj na sastave delegacija, pri čemu je sedamdesetih godina ulazila i u izravan sukob s drugim akterima, naročito s Predsjedništvom SFRJ. Taj je sukob kasnije eskalirao i postao vidljiv prigodom Titova posjeta stranim zemljama (Zapisnik KPR I-II /1972, SSSR).

18 Primjerice, za posjeta Grčkoj od 10. do 13. svibnja 1976. Tito je dobio poseban makedonski dokument o odnosima s Grčkom. Bilo je predviđeno da u sastavu delegacije bude i predsjednik Izvršnog vijeća Makedonije Blagoje Popov. Kada je Tito posjećivao druge zemlje, uvijek je u delegaciji bio predstavnik neke republike, ovisno o tome koja je bila najviše zainteresirana za posjet toj zemlji. No grčki ambasador u SFRJ Economides "u privatnom svojstvu" zatražio je od Titova kabineta da Blagoje Popov ne bude u delegaciji. Economidesova molba bila je uslišana pa je, umjesto makedonskoga, u posjet išao crnogorski predstavnik Veljko Milatović. Vjerojatno je tako odlučeno i zato što je to bio prvi Titov posjet Grčkoj nakon pada vojne hunte 1974. pa mu je bilo posebno važno uspostaviti dobre odnose s tom zemljom. Tito je svojedobno upozorio Makedoniju i Sloveniju da ne vode samostalne vanjske politike i ne pokušavaju gurati jugoslavensku vanjsku politiku u smjeru koji odgovara samo njima, izlažući tako Jugoslaviju dodatnim rizicima. teri procesa odlučivanja. U Ustavu 1946. i Ustavom zakonu 1953. nije, naime, bilo ni riječi o utjecaju republika i pokrajina na oblikovanje vanjske politike. No čl. 113. Ustava 1963. daje mogućnost da republike i autonomne pokrajine budu konzultirane o vanjskoj politici. Blagović-Posavec (1973: 212) smatra da je ključan korak učinjen amandmanima na republičke ustave 1969. koji su "obvezivali republike na sudjelovanje u utvrđivanju politike federacije u odnosima $\mathrm{s}$ inozemstvom, (te) na brigu o provođenju i poduzimanju mjera za unapređenje međunarodnih odnosa". I savezni Ustav 1974. naglasio je "princip ravnopravnog sudjelovanja i odgovornosti republika i autonomnih pokrajina u organima i organizacijama federacije u utvrđivanju i provedbi politike federacije kao i neophodnosti njihove suglasnosti prilikom donošenja odluka od značaja za cijelu federaciju" (212). Odatle proizlazi "da se novi odnosi između federacije i republika i autonomnih pokrajina, a koji se odnose na daljnje proširivanje kompetencija republika, što ujedno predstavlja i jednu od najrelevantnijih novina $\mathrm{Na}$ crta novog Ustava SFRJ, na svojevrstan način odražavaju i na područje vanjske politike. Iako republike mogu u međunarodnim odnosima djelovati samo kao organi federacije čvrsto se pridržavajući određenih okvira vanjske politike Jugoslavije i uz puno poštovanje zaključenih međunarodnih ugovora, Nacrt Ustava u članu 259. ostavlja dosta značajna prava republikama i autonomnim pokrajinama da u međunarodnim odnosima, uz spomenute ograde, i same ostvaruju različite oblike suradnje s 'organima $\mathrm{i}$ organizacijama drugih država, isto tako i s međunarodnim organima i organizacijama’ za koje su zainteresirane" (213).

U skladu s novim načelima, sredinom šezdesetih godina osnovani su savjeti za odnose s inozemstvom pri republičkima izvršnim tijelima. U Hrvatskoj je 
takav savjet osnovan 1967. pri Izvršnom vijeću, to jest republičkoj vladi. Deset godina kasnije Savjet je, na osnovi posebnog zakona iz 1977, postao Republički komitet za odnose s inozemstvom kojemu je predsjedavao član Izvršnog vijeća. Od 1968. do 1977. pri Izvršnom vijeću djelovala je i Komisija za kulturne veze s inozemstvom. I Centralni komitet SKH imao je Komisiju za međunarodnu politiku i odnose u međunarodnome radničkom pokretu, a slično tijelo imao je i Socijalistički savez radnog naroda Hrvatske (SSRNH). U skladu s političkom orijentacijom na nesvrstane i postkolonijalne zemlje, u Zagrebu je 1963. osnovan Institut za proučavanje Afrike, koji je 1971. postao Institut za zemlje u razvoju, a 1989. Institutu za razvoj i međunarodne odnose.

Blagović-Posavec ističe da je Ustav 1974. prvi put predvidio mogućnost vanjskopolitičkog djelovanja općina, organizacija udruženog rada i radnih zajednica. Ta je novina bila izraz ideološkog zaokreta u unutarnjoj politici Jugoslavije koja se - posebno nakon sloma Hrvatskog proljeća ${ }^{19}$ i srpskog liberalizma - vratila marksističkoj ideologiji nadajući se da ona može biti kohezivna politička snaga. Važan dio doktrine samoupravljanja bila je ideja decentralizacije koja se nije smjela zadržati na razini republika i pokrajina nego je trebalo biti "spuštena" i na razine općina, koje su

19 O tome zaokretu i povezanosti Hrvatskog proljeća s vanjskom politikom Jugoslavije v. Batović 2017. Batovićeva je knjiga važna i zato što pokazuje da su republike već u razdoblju Hrvatskog proljeća (1967-1971), a naročito nakon 1969 , bile akteri vanjske politike, makar tako što su nastojale utjecati na oblikovanje vanjske politike onih zemalja koje su imale konzulate u njima. Batovićevo istraživanje otkriva, primjerice, prilične razlike $\mathrm{u}$ analizama koje su u britanski Foreign Office slali veleposlanik Ujedinjenog Kraljevstva iz Beograda i konzul iz Zagreba. Slične su razlike uočljive i u analizama veleposlanstva i konzulata SAD-a. trebale biti temeljne jedinice političkog sustava i glavna mjesta političkog organiziranja "radnih ljudi i građana". Ustavno spominjanje općina, a posebno "organizacija udruženog rada" i "radnih zajednica", bila je formalnost, jer u stvarnosti općine nisu ni pokušavale utjecati na međunarodne odnose, iako su imale sredstva za to (primjerice, Vijeća općina u republičkim skupštinama).

Republike i pokrajine imale su i neke posebne interese koje su nastojale promovirati i za njih dobiti potporu drugih aktera vanjske politike, ponajprije Tita. Slovenija i Hrvatska bile su posebno zainteresirane za neriješena pitanja razgraničenja s Italijom, koja su uređena tek Osimskim sporazumom 1975, te za status hrvatske i slovenske manjine u Austriji. One su 1967. i 1968. sudjelovale $\mathrm{u}$ pregovorima Jugoslavije s Italijom o granici na moru i sporazumu o ribarstvu. Predstavnici Izvršnog vijeća SR Hrvatske sudjelovali su i u radu zajedničke talijansko-jugoslavenske komisije za određivanje graničnih prijelaza te u jugoslavensko-mađarskoj komisiji i u komisiji za manjine (Batović 2017: 105). Iako su sedamdesetih godina poboljšani odnosi s Austrijom i Italijom, status slovenske i hrvatske manjine u Austriji remetio je potpunu normalizaciju međudržavnih odnosa. ${ }^{20}$ Hrvatska je imala i poseban interes za privredne investicije u inozemstvu u kojima su sudjelova-

${ }^{20} \mathrm{O}$ pitanjima jugoslavensko-austrijskih odnosa, koja su se ticala statusa slovenske i hrvatske manjine u Austriji, zanimljivo je govorio Edvard Kardelj u polemičnom intervjuu austrijskom časopisu Profil 13. veljače 1976. Kardelj je prigovorio Austriji da ne provodi Državni ugovor nego da vodi politiku nasilne asimilacije koja vodi $\mathrm{k}$ nestajanju tih dviju manjina. Iako je bio visoki jugoslavenski funkcionar, član Predsjedništva SFRJ, Kardelj je govorio i kao Slovenac koji zastupa interese koji su bili važniji Sloveniji (i Hrvatskoj) nego ostalim republikama i pokrajinama (Kardelj 1979: 176-189). 
le hrvatske tvrtke Rade Končar, Ingra, Ina, brodogradilišta i dr. U kadrovskoj politici Hrvatska je inzistirala na tome, ponekad bezuspješno, da dobije diplomatska mjesta u zemljama u kojima živi hrvatska dijaspora, primjerice u konzulatu u Pittsburgu gdje je bilo sjedište Hrvatske bratske zajednice, te u Austriji i Njemačkoj u kojima su bili brojni hrvatski gastarbajteri. Prema popisu stanovništva 1971, oko 39 posto ukupnog broja iseljenika i radnika na privremenom radu u inozemstvu, koji su bili jugoslavenski državljani, bili su Hrvati, a 28,5 posto Srbi (Batović 2017: 17).

Makedonija je željela da jugoslavenska vanjska politika oštrije reagira na bugarsko i grčko osporavanje nacionalnog identiteta Makedonaca i makedonskog jezika. ${ }^{21} \mathrm{~S}$ Grčkom je bilo otvoreno i pitanje povratka mnogih Makedonaca koji su sudjelovali u grčkome građanskom ratu (1944-1949), a koji su se kasnije kao izbjeglice doselili u Jugoslaviju, najviše u Makedoniju. Interpretacija uloge Bugarske u Drugome svjetskom ratu bila je trajno sporno pitanje u bugarsko-jugoslavenskim odnosima. Ono se isticalo i zato što je Bugarska bila najvjernija sovjetska saveznica pa se u Jugoslaviji stjecao dojam da je bugarsko osporavanje makedonskog jezika - obrazlagano stavom kako države ne priznaju jezike nego države, te da stoga to pitanje ne može biti predmetom bilateralnih razgovora ${ }^{22}$ - zapravo prijetnja koja nadilazi bilateralno značenje. Tito je u oba slučaja bio donekle popustljiv,

${ }^{21} \mathrm{O}$ Titovu povremenom nezadovoljstvu makedonskim inicijativama, idejama i izjavama u vezi s jugoslavensko-grčkim odnosima v. Jakovina (2013).

22 O razlikama u jugoslavenskome i bugarskom gledanju na makedonsko pitanje v. Zapisnik s bilateralnog susreta Josipa Broza Tita i Todora Živkova, održanog na marginama Konferencije o europskoj sigurnosti i suradnji u Helsinkiju 30. srpnja 1975. (AJ/ KPR, I-2/1975/KEBS). iako je bio mnogo kritičkiji prema Bugarima nego Grcima, posebno sedamdesetih godina kada su poslije pada vojne diktature obnovljeni bilateralni odnosi s Grčkom.

Neke vanjskopolitičke aktivnosti bile su dopuštene i pokrajinama. Kosovo je razvijalo odnose s Albanijom, osobito na području kulture i prosvjete, što je izazivalo otpor i kritike u Srbiji. Kada su izbile proturežimske demonstracije na Kosovu 1981, pojedini predstavnici srpskoga i jugoslavenskog političkog vrha isticali su kako su upravo odnosi s Albanijom jedan od uzroka "iredentizma", "kontrarevolucije" i "separatizma na Kosovu".

Značajan iskorak u "republikanizaciji" vanjske politike, makar normativno, bilo je prihvaćanje amandmana 35 . na Ustav SFRJ 1971. Njime je prihvaćeno da se "međunarodni ugovori koji zahtijevaju donošenje novih ili izmjenu postojećih republičkih odnosno pokrajinskih zakona ili iz kojih proizlaze posebne obaveze za jednu ili više republika ili autonomnih pokrajina zaključuju uz suglasnost republičkih odnosno pokrajinskih skupština". Republikama i pokrajinama omogućeno je da "ostvaruju suradnju s organima i organizacijama drugih država i međunarodnim organima i organizacijama, u okviru utvrđene međunarodne politike SFRJ i međunarodnih ugovora".

U stvarnosti, uloga republičkih i pokrajinskih skupština ostala je drugorazrednom, ali je i u federaciji uloga Savezne skupštine bila marginalizirana. Jedna analiza o kojoj se raspravljalo na sjednicama tijela za pitanja međunarodnih odnosa u Hrvatskoj, a koju je 1970. napisao Davorin Rudolf, pokazala je da o vanjskoj politici još ne odlučuje Savezna skupština, iako je prema Ustavu 1963. imala nadležnosti u definiranju i nadgledanju vanjske politike. Rudolfova 
analiza pokazuje da se od 1963. do 1967. u Saveznoj skupštini raspravljalo o 2.136 točaka dnevnog reda i da se samo 60 točaka ticalo vanjske politike (Batović 2017: 110). Taj je trend nastavljen 1967. i 1968, u dvjema po mnogočemu ključnim godinama jugoslavenske vanjske politike. Republike, posebno Hrvatska, u tom su razdoblju, koje danas nazivamo Hrvatskim proljećem, tražile decentralizaciju na svim područjima, pa i u vanjskoj politici, zagovarajući demokratizaciju vanjske politike.

Kada su dobile ovlasti za samostalnije djelovanje i u međunarodnim odnosima, hrvatske vlade počele su ih koristiti, pa je predsjednik Izvršnog vijeća Dragutin Haramija u lipnju 1970. posjetio Austriju, u ožujku 1971. Mađarsku, a u lipnju te godine i Italiju, odnosno regiju Furlaniju-Julijsku krajina (Batović 2017: 118). Od 1978. Hrvatska i Slovenija sudjelovale su, i to kao dvije suosnivačice, u Radnoj zajednici Alpe-Jadran, koju su formirale s Autonomnom regijom Furlanijom-Julijskom krajinom, austrijskom pokrajinama Koruškom, Gornjom Austrijom i Štajerskom te Regijom Veneto. Osim njih, u radu zajednice sudjelovale su kao promatračice Slobodna Država Bavarska i austrijska pokrajina Salzburg. Iako je karakter te koordinacije bio povezan s drugim javnim politikama - informacijskom, kulturnom, prometnom, poljoprivrednom, turističkom, ekološkom i dr. ${ }^{23}$ - činjenica da su dvije

${ }^{23}$ U Zajedničkoj izjavi u povodu osnivanja Radne zajednice Alpe-Jadran piše da su joj zadaće "informativno-stručno raspravljanje i koordiniranje pitanja koja su u interesu njezinih članica". "Poglavito će se raspravljati o sljedećim pitanjima: prekoalpske prometne veze, lučki promet, dobivanje i prijenos energije, poljoprivreda, šumarstvo, vodoprivreda, turizam, zaštita čovjekove okoline, zaštita prirode, očuvanje kulturnog i rekreacijskog prostora, prostorno planiranje, razvoj naselja, kulturne veze i odnosi, (te) međusobne veze znanstvenih ustanova". http://www.mvep. republike razvijale bliske odnose $\mathrm{s}$ talijanskim regijama i austrijskim pokrajinama naišla je na kritiku centralističkih krugova u Jugoslaviji. Osamdesetih godina, a posebno potkraj tog desetljeća, centralisti i srpski nacionalisti vidjeli su u hrvatskome i slovenskom sudjelovanju u zajednici Alpe-Jadran separatizam, što je bilo potpuno neutemeljeno. No to je činilo te dvije republike akterima u prvim oblicima transgranične suradnje, a time i u odnosima s drugim regijama odnosno poddržavnim akterima. Takav je oblik suradnje trebao svjedočiti i o novoj politici koja je u trokutu Italija-Austrija-Jugoslavija nastala u doba detanta, posebno neposredno nakon potpisivanja Osimskih sporazuma, te kao rezultat novog duha Helsinkija.

Kadrovska politika bila je najizravniji način utjecaja pojedinih republika na jugoslavensku vanjsku politiku, ali i međusobne sukobe republika i pokrajina. Republike su htjele veću kontrolu nad zapošljavanjem u diplomaciji, a posebno nad procesom odlučivanja o imenovanju veleposlanika, generalnih konzula i prvih tajnika u veleposlanstvima. Hrvatska je nakon 1966. tvrdila da velik broj zaposlenih u Saveznom sekretarijatu za inozemne poslove potječe iz obavještajne zajednice i da je njezin utjecaj, naročito na kadrovsku politiku, prevelik. Izvršno vijeće, koje je vodila Savka Dabčević-Kučar, tražilo je i povlačenje nekih "hrvatskih kadrova" s kojima hrvatska vlast nije bila zadovoljna. Čelnici Saveznog sekretarijata Marko Nikezić i Mirko Tepavac protivili su se prevelikoj "republikanizaciji" kadrovske politike smatrajući da je politički utjecaj na profesionalnu diplomaciju ionako prevelik. Tepavac je 1969. objavio da je od 69 veleposlanika čak 41 postavljen "političkim putem", a samo je 28 došlo

$\mathrm{hr} / \mathrm{hr} /$ vanjska-politika/multilateralni-odnosi-staro-ijvhj/radna-zajednica-alpe-jadran--opcenito/zajednicka-izjava/ (pristupljeno 19. siječnja 2018). 
iz profesionalne diplomacije (Batović 2017: 114). Naveo je i slučajeve u kojima su diplomati u veleposlanstvima pokazali da se osjećaju previše vezanima za republička vodstva kojima šalju izvještaje bez znanja veleposlanika. Sličan trend podjele primijetio je i američki veleposlanik u Jugoslaviji William Leonhart, koji je 1969. javljao svojoj vladi da su republičke kvote postale najveći problem jugoslavenske diplomacije (Batović 2017: 117).

Hrvatska je, inače, 1969. imala natprosječan broj veleposlanika: 20 je bilo iz Hrvatske, 17 iz Srbije, 11 iz Bosne i Hercegovine, a ostali su došli iz drugih republika. No nacionalni sastav Saveznog sekretarijata za inozemne poslove bio je za Hrvate nepovoljniji: od 1.667 zaposlenih, Srba je bilo 63,1 posto, a Hrvata 14,4 posto. Svi su bili nezadovoljni: Hrvati zato što ih nema više među zaposlenima, a Srbi zato što ih nema više na najvišim pozicijama. Kada su se odnosi pokušali promijeniti, otkrilo se da su samo neki predloženici iz republičkih kvota zadovoljavali kriterije diplomatske službe (znanje stranih jezika, stručne kvalifikacije, sigurnosne provjere i dr.). Od 23 kandidata koje je Saveznom sekretarijatu za inozemne poslove 19681969. predložila hrvatska vlada, zaposleno je osam, a samo su četiri postavljena na mjesta za koja su predloženi. Hrvatska je stoga zaključila da se njezini interesi zanemaruju i ignoriraju (Batović 2017: 112). Istodobno, i Hrvatska je u nekim slučajevima blokirala imenovanja visokih dužnosnika koje je smatrala nekvalificiranima ili je mislila da bi na njihova mjesta trebali doći kandidati iz Hrvatske. Primjerice, imenovanje Miše Pavićevića veleposlanikom u Italiji kao kandidata iz Crne Gore blokirale su Hrvatska i Slovenija (Batović 2017: 117).

Lončar tvrdi da je utjecaj republika i pokrajina na kadrovsku politiku bio mnogo veći poslije Titove smrti 1980.
Kada je on bio savezni sekretar za inozemne poslove (1987-1991) sva su imenovanja veleposlanika morala biti usuglašena sa svim republikama i pokrajinama, pa je njihova moć bila velika. Prije no što je imenovan saveznim sekretarom za vanjske poslove, Lončar je obišao sve republike i pokrajine. U razgovoru s autorom, Lončar je istaknuo da su republike bile uključene u vanjsku politiku i tako što su u programima stranih šefova država ili vlada koji su dolazili u Jugoslaviju najčešće bili i posjeti nekoj republici: Richard Nixon posjetio je Hrvatsku, Helmut Schmidt Crnu Goru, Hua Guofeng Makedoniju itd. I tako se htjelo pokazati da je Jugoslavija federativna država. Iz gradiva dostupnog $\mathrm{u}$ arhivu Josipa Broza Tita vidlivo je i da su predstavnici republika i pokrajina bili uključeni u razgovore tijekom posjeta stranih državnika, kao i Titovih posjeta drugim zemljama.

\section{Zaključak}

Analizom jugoslavenske vanjske politike od 1943. do 1992. može se zaključiti da su procesi odlučivanja o njoj s vremenom značajno evoluirali. U prvoj poslijeratnoj fazi Tito je djelovao autokratski. Iako se oslanjao na neke suradnike, većinu odluka donosio je neformalno i samostalno. U kasnijim razdobljima, kada se država konsolidirala i kada je uspostavljena funkcionalna struktura, razvija se interakcija između Tita kao najmoćnijega, umnogome nadsistemskog pa i protusistemskog aktera, i strukture. U tom su odnosu postojali jedan moćan akter, Tito, i najmanje tri podstrukture na razini federacije koje su bile sastavni dijelovi birokratskog sustava, a to su bili državni odnosno Savezni sekretarijat za inozemne poslove, partijsko vodstvo i kabinet Predsjednika Republike. Analiza odnosâ podstruktura mogla bi "ispričati priču" o sadržaju i metodi odlučivanja u socijalističkoj Jugoslaviji općenito. Riječ 
je o mnogo široj analizi odnosa između moćnog pojedinca koji donosi odluke i strukture koju je stvorio, ali koja s vremenom gradi svoju samostalnost, oblikuje vlastita pravila djelovanja i ne želi preveliku nestabilnost koju definicijski stvara autoritarni "intervencionistički" vođa.

Evolucija se očituje i u nastanku vertikalnih odnosa između glavnog aktera i poddržavnih razina - republika i pokrajina. Iz analize je jasno kako se ne smije zanemariti ni ta vertikalna dimenzija ako se želi razumjeti karakter odlučivanja o vanjskoj politici u Jugoslaviji. Iako je Tito do kraja života ostao moćan politički akter, s vremenom je proces odlučivanja znatno pluraliziran i na horizontalnoj i na vertikalnoj osi. Nakon što je ustanovljeno Predsjedništva SFRJ početkom sedamdesetih godina, i institucionalno je ograničena autokratska moć Predsjednika Republike. Moglo bi se ustvrditi da je u tom trenutku Titova moć značajno ojačana podrškom izvana. I SAD i SSSR oslanjali su se izravno na Tita, smatrajući ga najznačajnijim, ako ne i jedinim faktorom stabilnosti Jugoslavije. Obje su države smatrale kako se jednostavnije i sigurnije, a vjerojatno i učinkovitije, osloniti na izravne razgovore s Titom nego eksperimentirati s kolektivnim šefom države. Titova iznimna pozicija u pokretu nesvrstanih zemalja također je ojačala njegov položaj, koji je sedamdesetih godina postao gotovo izvansistemski. Naime, Ustavom SFRJ 1974. stvoren je politički sustav sa svim institucijama koje su mogle zamijeniti Tita, te je on postao više "tolerirana iznimka" nego nužan akter. Paralelne institucije, koje su ubrzo dospjele pod snažan utjecaj različitih interesa republika i pokrajina, preuzele su stvarnu moć, ostavljajući Titu formalne funkcije i svodeći ga na mitsku i ritualnu figuru. Stoga je prijenos vlasti neposredno nakon njegove smrti bio bezbolan i jednostavan. No poslije njegove smrti struktura je ostala bez svoga glavnog aktera, ali je zato postala potpuno neosobna i "birokratizirana". Kao što je Titov sustav uključivao mnoge interese i utjecaje te je s vremenom postajao sve pluralističniji, tako je novi posttitoistički sustav sadržavao elemente autoritarnosti i autokratičnosti, ali ne više toliko na saveznoj koliko republičkima i pokrajinskim razinama. Neke od tih tendencija ubrzo su postale vidljivima u pokušajima pojedinaca da ovladaju strukturom kako bi je razbili ili radikalno preoblikovali prema svojoj mjeri, primjerice "antibirokratskom revolucijom". No pokušaj nametanja novoga autokratskog vođe koji bi stvarao svoju novu strukturu vodio je $\mathrm{k}$ raspadu same strukture, odnosno jugoslavenske države. 


\section{Literatura}

Batović, Ante. 2017. The Croatian Spring: Nationalism, Repression and Foreign Policy under Tito. London: I. B. Tauris.

Blagović, Božica. 1974. Metodologija nauke o međunarodnim političkim odnosima u jugoslavenskoj teoriji. Politička misao. (9) 3: 44-51.

Blagović-Posavec, Božica. 1973. Vanjska politika u nacrtu novog Ustava SFRJ. Politička misao. (10) 3: 211-216.

Carlsnaes, Walter. 2012. Actors, structures, and foreign policy analysis. U: Smith, Steve i dr. (ur.). Foreign Policy: Theories, Actors, Cases. Oxford: Oxford University Press, str. 113-129.

Hudson, Valerie M. 2014. Foreign Policy Analysis: Classic and Contemporary Theory. Lanham: Rowman i Littlefield.

Ilić, Marina. 2016. Problem agent-structure: teorijski nalazi i implikacije za studije građanskih ratova. U: Jović, Dejan. (ur.). Konstruktivističke teorije medunarodnih odnosa. Zagreb: Fakultet političkih znanosti, str. 147-176.

Jakovina, Tvrtko. 2011. Treća strana hladnog rata. Zaprešić: Fraktura.

Jakovina, Tvrtko. 2013. Neprijatelji ili samo loši susjedi? Jugoslavija i balkanske zemlje 1970-ih i 1980ih. U: Duraković, Lada, Matošević, Andrea. (ur.). Socijalizam na klupi: jugoslavensko društvo očima nove postjugoslavenske humanistike. Pula i Zagreb: Srednja Europa, Sveučilište Jurja Dobrile u Puli i Sa(n)jam knjige u Istri, str. 47-76.

Jović, Dejan. 2011. Hrvatska vanjska politika pred izazovima članstva u Europskoj uniji. Politička misao. (48) 2: 7-36.

Jović, Dejan. (ur.). 2016. Konstruktivističke teorije međunarodnih odnosa. Zagreb: Fakultet političkih znanosti.
Kardelj, Edvard. 1979. Medunarodni odnosi i nesvrstanost. Izbor iz dela VI. Beograd: Komunist.

Kassimeris, Christos. 2009. The Foreign Policy of Small States. International Politics. 1: 84-101.

Keohane, Robert O. (ur.). 1986. Neorealism and Its Critics. New York: Columbia University Press.

Kissinger, Henry. 2003. Treba li Amerika vanjsku politiku: prema diplomaciji 21. stoljeća. Zagreb: Golden marketing.

Luša, Đana, Mijić, Petra. 2012. Vanjska politika malih država - normativna moć kao faktor utjecaja u međunarodnim odnosima. Politička misao. (49) 3: 39-65.

Maas, Matthias. 2009. The Elusive Definition of the Small States. International Politics. (46) 1: 65-83.

Mates, Leo. 1974. Koegzistencija. Zagreb: Školska knjiga.

Mearsheimer, John. 2013. Strukturalni realizam. U: Jović, Dejan. (ur.). Teorije međunarodnih odnosa: realizam. Zagreb: Politička kultura, str. 87-104.

Molloy, Sean. 2006. The Hidden History of Realism: A Genealogy of Power Politics. New York i Basingstoke: Palgrave Macmillan.

Novičić, Žaklina. 2009. Neorealizam Keneta Volca: analiza strukturalne teorije medunarodnih odnosa. Beograd: Institut za međunarodnu politiku $\mathrm{i}$ privredu.

Petek, Ana. 2012. Što su hrvatske javne politike? Političke analize. (3) 11: 37-45.

Putnam, Robert. 1988. Diplomacy and Domestic Politics: The Logic of Two-Level Games. International Organization. (42) 3: 427-460.

Rosenau, James. 1966. Pre-Theories and Theories of Foreign Policy. U: Farrell, Barry R. (ur.). Approaches to Compar- 
ative and International Politics, New York: John Wiley.

Selinić, Slobodan. 2013. Partija i diplomatija u Jugoslaviji, 1945-1952. Beograd: Institut za noviju istoriju Srbije.

Selinić, Slobodan. 2014. Jugoslovenska diplomatija 1945-1950: stvaranje partijske diplomatije. Annales. (24) 4: 553-562.

Smith, Steve, Hadfield, Amelia, Dunne, Tim. (ur.). 2012. Foreign Policy: Theories, Actors, Cases. Oxford: Oxford University Press.

Snyder, Richard C., Bruck, Henry W., Sapin, Burton. 1954. Decision-Making as an Approach to the Study of International Politics. Basingstoke: Palgrave Macmillan.

Šoljan, Nina. 2011. Vanjska politika: pristupi, razine analize, dimenzije. Anali Hrvatskog politološkog društva. (8) 1 : 7-20.

Tepavac, Mirko, Nenadović, Aleksandar. 1998. Mirko Tepavac: sećanja i komentari. Beograd: Samizdat.

Vukadinović, Radovan. 1970. Male države i politika nesvrstavanja. Politička misao. (7) 3-4: 407-422.

Vukadinović, Radovan. 1980. Osnovni okviri istraživanja vanjske politike. Politička misao. (17) 1-2: 159-174.

Vukadinović, Radovan. 1981. Osnove teorije vanjske politike. Zagreb: CKD $\mathrm{SSOH}$.

Vukadinović, Radovan. 1988. Jugoslavenska vanjska politika: novo vrijeme i novi zadaci. Politička misao. (25) 2: 3-12.
Vukadinović, Radovan. 1989. Osnove teorije medunarodnih odnosa $i$ vanjske politike. Zagreb: Školska knjiga.

Vukadinović, Radovan. 2005. Teorije vanjske politike, Zagreb: Politička kultura.

Zehfuss, Maja. 2002. Constructivism in International Relations: The Politics of Reality. Cambridge: Cambridge University Press.

Žarković, Petar. 2017. Sipovska koncepcija jugoslovenske spoljne politike: DSIP u središtu unutarpartijskih sporenja. Tokovi istorije. 1: 97-121.

Wallerstein, Immanuel. 1974. The modern world system. London: Academic Press.

Waltz, Kenneth. 1979. Theory of International Relations, London: McGraw-Hill.

Waltz, Kenneth. 2001. Man, the State and War: A Theoretical Analysis. New York: Columbia University Press.

Waltz, Kenneth. 2008. Realism and International Politics. New York i London: Routledge.

Waltz, Kenneth (Kenet N. Volc). 2008a. Teorija medunarodne politike. Beograd: Centar za civilno-vojne odnose.

Wendt, Alexander E. 1987. The agent-structure problem in international relations theory. International Organization. (41) 3: 335-370.

Wendt, Alexander (Vent, Aleksandar). 2014. Društvena teorija međunarodne politike. Beograd: Fakultet političkih nauka. 


\title{
Foreign policy analysis: agency and structure in socialist Yugoslavia
}

\begin{abstract}
Unlike the great majority of analyses that have taken the historiographic perspective, this study of socialist Yugoslavia's foreign policy, focusing on the Josip Broz Tito era, is the first of its kind to provide a perspective of political science. The first section of this article provides an overview of the main elements of foreign policy analysis, whereby the author focuses on the relationship between the actors and the structures as one of its inherent elements. The second section offers insight into the theoretical and methodological tenets on which the analysis of socialist Yugoslavia's foreign policy resides. The author argues that the foreign-policy decision-making process in Yugoslavia evolved between 1945 and 1980 as Tito, the chief decision-maker, increasingly had to take into account the structure and the multiple actors within that structure. Evidently, the decision-making processes were becoming more and more pluralized both horizontally, in the interaction between the Federal Secretariat for Foreign Affairs, party leadership and Tito's cabinet, and vertically - as seen from the influence the republics and provinces hadon federal decision-making. Though he remained the chief decision-maker, with time Tito's power became limited by other actors' influence, in particular after the Presidency of Yugoslavia was given extensive authority in the 1970s.
\end{abstract}

Key words foreign policy analysis, actors and structures, Yugoslav foreign policy, Josip Broz Tito, Croatian foreign policy 